\title{
Chilling requirement for seed germination and phenological observations on peach cultivars
}

\author{
Américo Wagner Júnior ${ }^{1}$, Claudio Horst Bruckner², José Osmar da Costa Silva², \\ Carlos Eduardo Magalhães dos Santos ${ }^{2}$, Leonardo Duarte Pimentel ${ }^{2}$, Sérgio Miguel Mazaro ${ }^{1}$
}

\begin{abstract}
In subtropical climate areas, the models and methods proposed to evaluate the chilling requirement of temperate fruit crops often do not provide satisfactory results, thus calling for the development of alternative techniques. The aim of this study was to evaluate the correlations between some phonological traits and chilling requirement for seed germination of 18 peach cultivars and one nectarine cultivar. Two experiments were installed separately for the correlation studies. In experiment 1 , the phenological traits were observed in the field, while in experiment 2, the chilling requirement for 50 and 100\% seed germination of each cultivar was assessed. The number of days for beginning of bloom ( $\mathrm{r}=$ $\left.0.70^{* *}, 0.61 * *\right)$ and full bloom $\left(\mathrm{r}=0.72 * *, 0.76^{* *}\right)$ were both significantly correlated with the number of chilling units for $50 \%$ and $100 \%$ germination of seeds. The number of days for beginning of budding and dormancy break were both significantly correlated with the number of chilling units for $50 \%$ and $100 \%$ germination $\left(\mathrm{r}=0.48^{*}, 0.50^{*}\right.$, respectively). However, the same significant effect for these phenological traits was not found between chilling units and $50 \%$ germination of seeds, as well as between chilling units and harvest dates.
\end{abstract}

Key words: Prunus spp., peach, dormancy.

\section{RESUMO}

\section{Necessidade de frio para estratificação das sementes e observações fenológicas em cultivares de pessegueiro}

Em regiões de clima subtropical, os modelos e métodos propostos para avaliação da necessidade de frio das fruteiras de clima temperado não apresentam, muitas vezes, resultados satisfatórios. Isto demonstra a necessidade do desenvolvimento de alternativas para se estimar a necessidade de frio dessas plantas. Este trabalho teve como objetivo analisar as correlações entre os dados fenólogicos e a necessidade de frio das sementes de 18 cultivares de pessegueiro e um cultivar de nectarineira. Para realização dos estudos de correlação, foram realizados dois experimentos, separadamente, sendo o primeiro por acompanhamento das características fenológicas em campo e, o segundo, com o estudo da necessidade de frio acumulado, para germinação de 50 e de $100 \%$ das sementes, de cada cultivar. Houve correlação significativa entre o número de dias necessários para o início do florescimento $\left(\mathrm{r}=0,70^{* *}, 0,55^{*}\right)$ e plena floração $(\mathrm{r}=0,72 * *, 0,73 * *)$ e o número de unidades de frio acumulado, para germinação de 50 e de $100 \%$ das sementes estratificadas. O número de dias para o início da brotação e fim da dormência apresentou correlação significativa com o número de unidades de frio acumulado, para 50 e $100 \%$ de germinação $\left(r=0,48^{*}, 0,50 *\right.$, respectivamente).

Received:12/06/2012; Accepted: 28/11/2012.

${ }^{1}$ Agronomist Engineer, Doctor of Science. Departamento de Agronomia, Universidade Tecnológica Federal do Paraná, Campus Dois Vizinhos, Estrada para Boa Esperança, Km 04, Caixa Postal 157, 85660-000, Dois Vizinhos, Paraná, Brasil. americowagner@utfpr.edu.br (corresponding author); sergio@utfpr.edu.br

${ }^{2}$ Agronomist Engineer, Doctor of Science. Departamento de Fitotecnia, Universidade Federal de Viçosa, Campus Viçosa, Avenida Peter Henry Rolfs, s/n, Viçosa, Minas Gerais, Brasil.bruckner@ufv.br; joksilva7@yahoo.com.br; carlos.magalhães@ufv.br; agropimentel@yahoo.com.br 
Entretanto, o mesmo efeito significativo nestes dados fenológicos não foi observado para o número de unidades de frio acumulado, para 50\% de germinação, como, também, entre o número de unidades de frio acumulado para estratificação das sementes e a época de colheita dos frutos.

Palavras-chave: Prunus spp., pêssego, dormência.

\section{INTRODUCTION}

A great deal of research and genetic improvement has been done on peach, leading to important advances in understanding the crop development (Barbosa et al., 2010).

Selection in peach breeding programs is based on traits related to harvest potential and fruit quality to meet market needs, as well as adaptation to different climatic conditions (late frosts, chilling requirement, etc ...) (Moreno, 2005).

This fruit tree needs a certain amount of cold, varying with the cultivar, to break dormancy of seeds and buds resulting in seed germination and flowering. The cold triggers internal mechanisms, changing the nature and level of growth regulators involved in the control of the dormancy processes (Petri \& Herter, 2004).

However, the climatic conditions of peach producing areas in Brazil vary considerably, particularly with respect to temperatures during the rest period of the trees. The areas suitable for peach cultivation in southeastern Brazil receive mild winters with large thermal oscillation with chill unit accumulation ranging from 50 to 300 (Citadin, 2001).

The conversion of average hourly temperature into chill units is not solely the sum of hours with temperatures below $7.2{ }^{\circ} \mathrm{C}$, but a wider temperature range. The chill units accumulate daily until a particular cultivar reaches the end of dormancy.

The existing models and methods for evaluating the chilling requirements of plants in the field are generally used for agroclimatic zoning of the crop, but do not provide satisfactory results in many regions, which, in turn, can affect and impair the phenological evaluation. In these cases, the use of correlated traits may provide a better phenological characterization of individuals.

It is generally assumed that the basis for bud and seed dormancy is similar, ie, plants that have high winter chilling requirement produce seeds with the same requirement for stratification (Kester, 1969). However, the studies that led to this conclusion were performed with genotypes that need more chill hours, therefore the need to evaluate this process in cultivars with lower chilling requirement.
In case this is confirmed, the monitoring of seed germination in studies of endodormancy will facilitate selection in breeding programs, because it is a less cumbersome process than those involving whole plants.

This study aimed to analyze the correlations between the phenological traits days to full bloom, early bud development, break of dormancy and harvest, and the chilling requirements of seeds of 18 cultivars of peach and one cultivar of nectarine.

\section{MATERIAL AND METHODS}

The study was conducted in the Departamento de Fitotecnia, Universidade Federal de Viçosa, Viçosa (MG), Brazil. We analyzed 18 peach cultivars: Aurora-1, Alô Doçura, Relíquia, Talismã, Rei da Conserva, Colibri, Campinas 1, Setembrino, Bolão, Cristal, Ouromel, Real, Biuti, Marli, Premier, UFV 186, Convênio and Topázio and the nectarine cultivar Josefina, in the 2003/2004 production year.

The studied cultivars were planted at the Experimental Station of the Universidade Federal de Viçosa, in the municipality of Araponga - MG, in 1991. The spacing between rows was $6.0 \mathrm{~m}$ and between plants was $4.0 \mathrm{~m}$.

The experimental area is located within the coordinates $20^{\circ} 40^{\prime}$ south latitude and $42^{\circ} 31^{\prime}$ west longitude, altitude of $885 \mathrm{~m}$ and according to Köppen classification, the climate is of the Cwa type.

To perform the correlation studies, two experiments were conducted separately; Experiment 1 carried out the monitoring of phenological data in the field; and Experiment 2 studied the accumulated chilling requirements for induction of germination and germination of $50 \%$ and $100 \%$ of seeds of each cultivar.

\section{Experiment 1}

Eight mixed branches of the previous growth cycle of each cultivar, four per plant, with average length of $26 \mathrm{~cm}$ were individually identified for evaluation in the field under conditions of natural cold, before the dormant period (May 16). At this time, the total number of vegetative and flowering buds per branch was recorded. Weekly 
evaluations were done during the study period through observation and count of terminal and lateral vegetative buds, with green buds and open flowers. The estimated break dormancy of each individual was based on the date on which $50 \%$ of the vegetative buds sprouted or were at the green bud stage (Raseira et al., 1998). Full bloom was considered the time when $70 \%$ of flowers were open. Thus, data on the beginning of flowering and bud-burst, dormancy break, full bloom and harvest stage of each cultivar were recorded. Harvest stage was considered when fruit size reached maximum development and the green color of the skin background changed to yellowish-green or cream (Cantillano \& Sachs, 1984). Throughout the experimental period, temperatures were recorded hourly using an R-704 RATONA thermo-surveyor. During the experiment, cultural practices (fertilization, fruit thinning, pest control and weeding), except for the application of chemicals to break dormancy and winter pruning were performed in the collection of peach trees in study.

\section{Experiment 2}

For the evaluation of chilling requirement, open pollinated peaches at the harvest stage were picked from the 18 peach cultivars and one nectarine cultivar in November and December 2003, at the Experimental Station Araponga (Table 1). After harvest, the fruits were taken to the Postharvest Laboratory at UFV, Viçosa-MG, washed and depulped. Seeds were removed by breaking the endocarp using a mini-vice, sterilized with a fungicide solution (Benlate 500 to $15 \mathrm{~g} \mathrm{~L}^{-1}$ ) and placed in plastic bags (10 seeds/bag) containing filter paper soaked with the same fungicide solution used in the disinfection. The bags were sealed and taken to a cold room for stratification, at $5{ }^{\circ} \mathrm{C}$ (Selim et al., 1998; Wagner Júnior et $a l ., 2006)$, relative humidity of $85 \pm 2.5 \%$, in the dark. The seeds were observed for the beginning of radicle protrusion every two days. At the end of this process, the number of accumulated chill units when the seeds reached $50 \%$ and $100 \%$ germination and the days required to initiate germination were recorded. The radicle protrusion was used as a reference to visibly mark the beginning of these processes. The experiment was arranged in a complete randomized design with four replications of ten seeds each. The number of days to the onset of germination and accumulated chill units required for germination of $50 \%$ and $100 \%$ of the seeds were subjected to analysis of variance and means were grouped by Scott-Knott (á = 0.05) using the Genes software (Cruz, 2006). For convertion of temperature in chilling units, we used the model developed by Richardson et al. (1974), known as the Utah model. The model assigns one chilling unit for every full hour of a plant's exposure to temperatures between 2.5 and $9.1^{\circ} \mathrm{C}$.

\section{Correlation analysis}

Pearson correlation analysis was performed between the number of days (from $1^{\text {st }}$ June) required to reach each phenological state of the plant in the field, and the number of accumulated chilling units for $50 \%$ and $100 \%$ germination.

\section{RESULTS AND DISCUSSION}

\section{Experiment 1}

\section{Chilling requirement in the field:}

The conversion of hourly temperatures during the experiment (Figure 1) into chilling units, using the Utah model (Richardson et al., 1974), for all cultivars [Campinas 1 (-124.5 chilling units ); Aurora-1, Biuti, Bolão, Colibri, Cristal, Real, Setembrino and Talismã (-134.5 chilling units); Ouromel (- 161.5 chilling units); UFV 186 (-191 chilling units); Josefina' (-220.5 chilling units); Relíquia (-225.5 chilling units); Premier ( -274 chilling units); Alô Doçura (339 chilling units); Topazio and Convênio (-371 chilling units); Marli and Rei da Conserva (-485 chilling units)] showed that there was negative chill accumulation to break dormancy, which indicates that this model is not ideal for estimating the chilling requirement in the field in climatic conditions similar to the Southeast. This demonstrates the need to develop other methodologies or models to estimate the chilling requirement of both vegetative and flowering buds for the cultivars in these conditions.

Records on observations of the 18 peach cultivars and one nectarine cultivar phenological events showed that cv. Campinas 1 was the first to start flowering and reach full bloom and dormancy break; however, cv. Real began sprouting sooner than the others (Table 1).

Herter \& Feliciano (1985) proposed that the early flowering can be used as an indicator of overall plant adaptation to climatic conditions in regions of low chill accumulation, and in this sense, besides cv. Campinas 1, the cultivars Aurora-1, Cristal, Ouromel, Josefina, Real, Relíquia, Setembrino, Talismã, Biuti, Colibri, UFV-186 and Topázio were more well adapted, starting their blooms in June.

In addition to the capacity of growing and flowering satisfactorily, peach trees grown in the southeast should produce early and good quality fruit. The early harvest is essential to improve the market price, since that enables offering the produce at a time of low supply, resulting in a better return to the grower.

Among the peach cultivars analyzed, Aurora-1, Real, Cristal, Setembrino, Marli, Premier, Colibri and Convênio reached to earlier harvest stage.

Albuquerque et al. (2000) evaluated 29 peach cultivars in the same production area during two years. Most of 
these cultivars were also included in this study. They found that cultivars Tropical, Régis, Rubro-sol, Centenário, Premier, Centenária, Marli, Aurora-1, Aurora-2, Josefina, Relíquia, Setembrino, Alô Doçura, Maravilha, Okinawa and Talismã were early ripening. These results were similar to those obtained for cultivars Premier, Marli, Aurora-1, Setembrino, Josefina, Relíquia and Alô Doçura in our study.

Cultivar Marli, despite having the earliest fruit ripening, was the latest for flowering and bud-bursting, as well as to full bloom and dormancy break. This earliness resulted from the rapid fruit development cycle in this cultivar. The longest time for cv. Marli to enter into flowering and full bloom stages can be explained by the need for greater heat accumulation, since this cultivar is less need for chilling accumulation compared with cv. Convênio (Raseira \& Nakasu, 1998), which showed advanced flowering and bud differentiation (Table 1).

According to Citadin (1999), it is possible that peach cultivars exist with low winter chilling requirement to break dormancy and high heat requirement to induce anthesis.

Chill accumulation in temperate fruit species is necessary to overcome the bud dormancy and regain the ability to grow. However, for the resumption of growth, ie, bud differentiation and flowering, it should occur a certain amount of heat accumulation, varying with the cultivar (Citadin et al., 2003).

In subtropical areas suitable for peach cultivation, the genetic improvement has pursued the development of

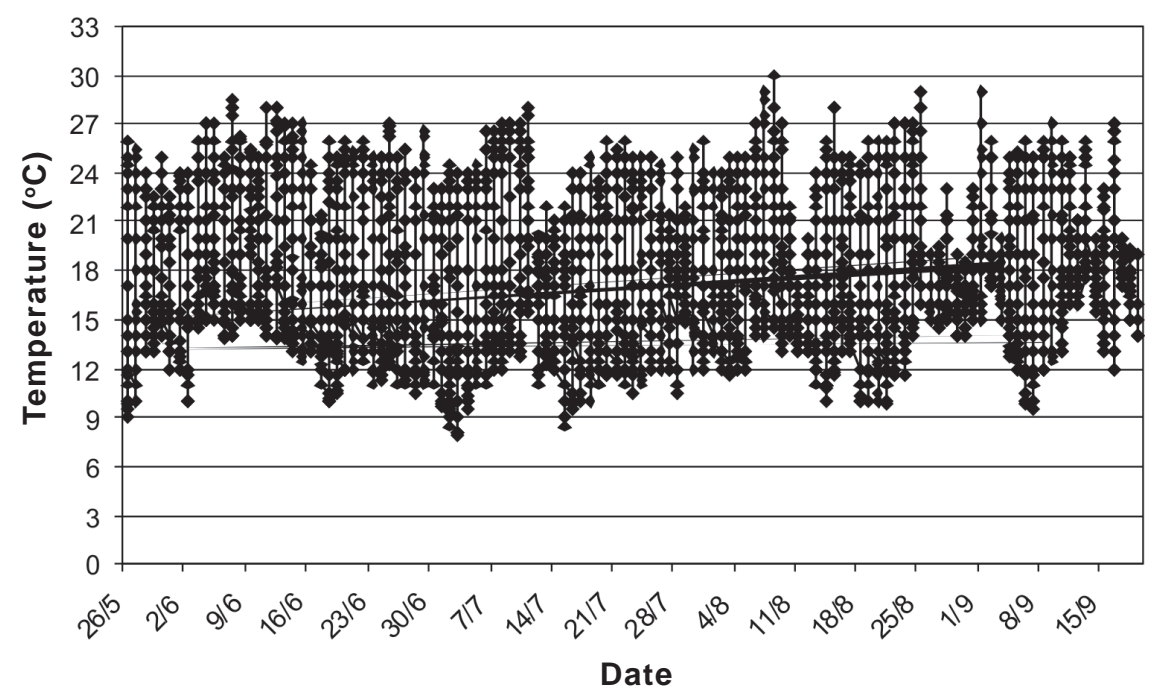

Figure 1. Hourly temperatures during the experimental period.

Table 1. Dates of early bloom, full bloom, bud-bust dormancy break and early harvest of 18 peach cultivars and one nectarine cultivar

\begin{tabular}{|c|c|c|c|c|c|}
\hline Cultivar & Early bloom & Full bloom & Early budding & Dormancy break $^{1}$ & Harvest stage \\
\hline Alô Doçura & $04 / 07$ & $11 / 7$ & $29 / 8$ & $5 / 9$ & $14 / 11$ \\
\hline Aurora-1 & $27 / 06$ & $11 / 7$ & $11 / 7$ & $25 / 7$ & $7 / 11$ \\
\hline Biuti & $27 / 06$ & $18 / 7$ & $4 / 7$ & $25 / 7$ & $21 / 11$ \\
\hline Bolão & $11 / 07$ & $25 / 7$ & $4 / 7$ & $25 / 7$ & $27 / 12$ \\
\hline Campinas 1 & $14 / 06$ & $20 / 6$ & $4 / 7$ & $11 / 7$ & $14 / 11$ \\
\hline Colibri & $20 / 06$ & $11 / 7$ & $18 / 7$ & $25 / 7$ & $7 / 11$ \\
\hline Convênio & $27 / 06$ & $15 / 8$ & $5 / 9$ & $12 / 9$ & $7 / 11$ \\
\hline Cristal & $20 / 06$ & $25 / 7$ & $4 / 7$ & $25 / 7$ & $7 / 11$ \\
\hline Josefina & $27 / 06$ & $15 / 7$ & $1 / 8$ & $15 / 8$ & $14 / 11$ \\
\hline Marli & $15 / 08$ & $19 / 9$ & $12 / 9$ & $19 / 9$ & $7 / 11$ \\
\hline Ouromel & $27 / 06$ & $1 / 8$ & $25 / 7$ & $1 / 8$ & $14 / 11$ \\
\hline Premier & $11 / 07$ & $15 / 8$ & $22 / 8$ & $29 / 8$ & $7 / 11$ \\
\hline Real & $20 / 06$ & $11 / 7$ & $20 / 6$ & $25 / 7$ & $7 / 11$ \\
\hline Rei da Conserva & $11 / 07$ & $15 / 8$ & $5 / 9$ & $19 / 9$ & $5 / 12$ \\
\hline Relíquia & $27 / 06$ & $18 / 7$ & $18 / 7$ & $22 / 8$ & $14 / 11$ \\
\hline Setembrino & $20 / 06$ & $18 / 7$ & $11 / 7$ & $25 / 7$ & $7 / 11$ \\
\hline Talismã & $20 / 06$ & $18 / 7$ & $4 / 7$ & $25 / 7$ & $21 / 11$ \\
\hline Topázio & $11 / 07$ & $22 / 8$ & $5 / 9$ & $12 / 9$ & $14 / 11$ \\
\hline UFV 186 & $27 / 06$ & $1 / 8$ & $25 / 7$ & $8 / 8$ & $5 / 12$ \\
\hline
\end{tabular}

${ }^{1} 50 \%$ of vegetative buds at the green bud stage. 
cultivars with phenological traits similar to those of cv. Marli. The delay in flowering avoids losses caused by late frosts and allows that pollination and fertilization occur at times when the temperatures are more favorable. Our results allow the recommendation that $\mathrm{cv}$. Marli should be used in future hybridizations within the peach breeding program of the Universidade Federal de Viçosa, as well as in others that aim for cultivars with late flowering and rapid fruit development cycle.

\section{Experiment 2}

\section{Seed chilling requirement:}

Analyses of variance showed that there were significant differences in the number of days required for the onset of germination and the accumulated chilling units needed to achieve $50 \%$ and $100 \%$ germination of the different cultivars. This shows that there is variability between the cultivars for these variables (Table 2). Variability is the necessary raw material used by the breeder in any breeding program.

Cultivars Campinas 1, Talismã and Ouromel required the shortest period (28 days) to start their germination, whereas cv. Bolão required the longest period (51 days) to begin the germination. Pérez-Gonzalez $(1990,1997)$ showed that the time to reach the onset of germination (less than 35 days of stratification) has been used in the pre-selection and selection of genotypes with low winter chilling requirement in the subtropics. Considering this criterion, in this work, the cultivars Aurora-1, Alô Doçura, Campinas 1, Josefina, Ouromel, Real, Relíquia, Talismã, Biuti, Rei da Conserva, Colibri and Topázio, all starting germination before 35 days could be selected (Table 2). Our findings demonstrate the similar chilling requirements of these cultivars as already described by Antunes (1985). The cultivars Cristal, Setembrino, Premier and UFV 186 also had low winter chilling requirement and started germination between 36 and 40 days of stratification.

The cultivars that required less chilling accumulation to achieve 50\% germination were Campinas 1 (796 CU), Rei da Conserva (870 CU), Josefina (898 CU), Ouromel (922 CU), Real (922 CU), Relíquia (952 CU), Aurora-1 (970 CU), Alô Doçura (976 CU), Talismã (978 CU), UFV 186 (1014 CU), Biuti (1055 CU), Colibri (1085 CU), Premier (1090 $\mathrm{CU}$ ) and Cristal (1156 CU). On the other hand, cv. Marli had the highest chilling requirement to achieve $50 \%$ of germination, ie, 1786 CU. In addition, two intermediate groups were formed, Topázio and Bolão and Convênio and Setembrino, requiring $1540 \mathrm{CU}$ and $1467 \mathrm{CU}$ in the first group and $1318 \mathrm{CU}$ and $1252 \mathrm{CU}$ in the second group to achieve $50 \%$ germination, respectively.

Table 2. Number of days to start germination and accumulated chilling units (CU) for germination of $50 \%$ and $100 \%$ of seeds of 18 peach cultivars and one nectarine cultivar

\begin{tabular}{|c|c|c|c|c|c|c|}
\hline \multirow[b]{2}{*}{ Cultivar } & \multicolumn{2}{|c|}{ Start of germination } & \multicolumn{2}{|c|}{$\mathbf{C U} * *$} & \multicolumn{2}{|c|}{ Differences in CU (\%) } \\
\hline & Days & $\mathbf{C} \mathbf{U}^{* *}$ & $\begin{array}{c}\mathbf{5 0 \%} \\
\text { germination }\end{array}$ & $\begin{array}{c}100 \% \\
\text { germination }\end{array}$ & $\begin{array}{l}\text { Start to100\% } \\
\text { germination }\end{array}$ & $\begin{array}{l}50 \text { to } 100 \% \\
\text { germination }\end{array}$ \\
\hline Aurora-1 & $34 \mathrm{~d}^{*}$ & 816 & $970 \mathrm{~d}$ & $1156 \mathrm{c}$ & 340 & 186 \\
\hline Alô Doçura & $31 \mathrm{e}$ & 744 & $976 \mathrm{~d}$ & $1126 \mathrm{c}$ & 382 & 150 \\
\hline Campinas 1 & $28 \mathrm{f}$ & 672 & $796 \mathrm{~d}$ & $922 \mathrm{c}$ & 250 & 126 \\
\hline Cristal & $38 \mathrm{c}$ & 912 & $1156 \mathrm{~d}$ & $1702 \mathrm{c}$ & 790 & 546 \\
\hline Josefina & $31 \mathrm{e}$ & 744 & $898 \mathrm{~d}$ & $1126 \mathrm{c}$ & 382 & 228 \\
\hline Ouromel & $28 \mathrm{f}$ & 672 & $922 \mathrm{~d}$ & $1204 \mathrm{c}$ & 532 & 282 \\
\hline Real & $33 \mathrm{~d}$ & 792 & $922 \mathrm{~d}$ & $1246 \mathrm{c}$ & 454 & 324 \\
\hline Relíquia & $31 \mathrm{e}$ & 744 & $952 \mathrm{~d}$ & $1492 \mathrm{c}$ & 748 & 540 \\
\hline Setembrino & $40 c$ & 960 & $1252 \mathrm{c}$ & $1588 \mathrm{c}$ & 628 & 336 \\
\hline Talismã & $28 \mathrm{f}$ & 672 & $978 \mathrm{~d}$ & $1206 \mathrm{c}$ & 534 & 228 \\
\hline Marli & $44 \mathrm{~b}$ & 1056 & $1786 \mathrm{a}$ & $2246 a$ & 1190 & 460 \\
\hline Premier & $38 \mathrm{c}$ & 912 & $1090 \mathrm{~d}$ & $1690 \mathrm{c}$ & 778 & 600 \\
\hline Biuti & $34 \mathrm{~d}$ & 816 & $1050 \mathrm{~d}$ & $1440 \mathrm{c}$ & 624 & 390 \\
\hline Rei da Conserva & $30 \mathrm{f}$ & 720 & $870 \mathrm{~d}$ & $1092 \mathrm{c}$ & - & - \\
\hline Colibri & $33 \mathrm{~d}$ & 792 & $1086 \mathrm{~d}$ & $1380 \mathrm{c}$ & 588 & 294 \\
\hline Bolão & $51 \mathrm{a}$ & 1224 & $1467 b$ & $1797 \mathrm{~b}$ & 573 & 330 \\
\hline UFV 186 & $38 \mathrm{c}$ & 912 & $1014 \mathrm{~d}$ & $1248 \mathrm{c}$ & - & - \\
\hline Topázio & $31 \mathrm{e}$ & 744 & $1540 \mathrm{~b}$ & $2313,75 \mathrm{a}$ & - & - \\
\hline Convênio & $40 \mathrm{c}$ & 960 & $1318 \mathrm{c}$ & $2272 \mathrm{a}$ & 1312 & 954 \\
\hline CV $(\%)$ & 5.13 & 13.63 & 22.86 & & & \\
\hline
\end{tabular}

Rev. Ceres, Viçosa, v. 60, n.2, p. 234-241, mar/abr, 2013 
The cultivars that needed the least accumulated chilling units to achieve $100 \%$ germination of seeds during stratification were Campinas 1, Rei da Conserva, Alô Doçura, Josefina, Aurora-1, Ouromel, Talismã, Real, UFV 186, Colibri, Biuti, Relíquia, Setembrino, Premier and Cristal. However, even with different times of stratification, all cultivars reached $100 \%$ germination.

The effect of stratification on the germination percentage observed in this study was also reported for other peach cultivars (Mehanna et al., 1985; Wagner Junior et al., 2006) and other species of the genus Prunus (Seeley \& Damavandy, 1985). Diaz \& Martin (1972) and Selim et al. (1998) found that during peach seed stratification at 5 ${ }^{\circ} \mathrm{C}$, the content of growth promoters such as gibberellins and indole acetic acid increased in seeds and the content of inhibitors such as abscisic acid decreased.

\section{Analysis of correlations}

The cultivars UFV 186 and Rei da Conserva were not included in the analysis of the differences between the chilling requirement for initiating germination and for achieving $100 \%$ germination and between the chilling requirement to reach $50 \%$ and $100 \%$ germination, because the cultivars were selected locally by farmers and thus we had no information on their genealogy.

Significant correlation was found between the number of accumulated chilling units for germination of $50 \%$ and $100 \%$ of the seeds and the number of days from 1 st. June to first bloom $(\mathrm{r}=0.70 * * ; 0.55 *)$ and full bloom ( $\mathrm{r}=0.72 * * ; 0.73 * *)$ (Table 3$)$. This can be explained, in part, by the common characteristics of dormancy in seeds and buds that require low temperatures and the action of same growth regulators such as gibberellins, cytokinins etc., to overcome this process. Perez-Gonzales (1990) found, in Mexico, a significant correlation between flowering time and the number of days for $80 \%$ germination of seeds in local peach genotypes $(r=0.71 * *)$ and genotypes introduced from other countries $(\mathrm{r}=0.87 * *)$ (United States, Italy, Spain and Brazil). Other studies also reported correlation between days to full bloom and seed chilling requirement for peach (Diaz \& Martin, 1972; Chang \& Werner, 1984; Guerriero \& Scalabrelli, 1985) and almond (Kester, 1969; Kester et al., 1977; Garcia-Worm et al., 2004).
In studies carried out by Westwood \& Bjornstad (1968) and Chang \& Werner (1984), the extent of seed dormancy was associated with chilling requirement for buds of the female parent start sprouting, as well as buds from both parents, as highlighted by Hauagge (1988) and Hauagge et al. (1989). In this study, we also found for the female parent significant correlation between the accumulated chilling units to reach $100 \%$ germination and both the number of days for early bud formation from 1st. June $\left(0.48^{*}\right)$ and dormancy break $(0.50 *)$.

However, the phenological data on budding (early budding and dormancy break) showed no significant correlation with the number of chilling units for $50 \%$ germination ( $\mathrm{r}=0.42^{\mathrm{ns}}$ and $\mathrm{r}=0.40^{\mathrm{ns}}$, respectively) ( Table 3 ). In this case, the non-occurrence of correlation may be related to the greater variation in chilling requirement for $50 \%$ germination among the genotypes. This variation, if derived from the embryo genotype, may indicate the suitability of the technique to perform selection aiming at low chilling requirement.

There is also lack of significant correlation between accumulated chilling units required for $50 \%$ and $100 \%$ germination and the dates on which fruits were at the harvest stage (Table 3). This demonstrates that the fruit development cycle is independent of seed chilling requirements.

Albuquerque (1997), studying 29 peach cultivars, found no correlation between the flowering and harvest periods. The same fact was observed in this study, although not shown in Table 3 (early bloom $x$ harvest stage $\left(r=0.14^{\mathrm{ns}}\right)$ and full bloom $x$ harvest stage $(r=0.02$ $\left.{ }^{n s}\right)$ ). The harvest stage depends on the time of flowering, but more accurately, on the period between flowering and ripening, which may vary between 60 and 200 days (Barbosa et al. 1990a; Barbosa et al. 1990b).

The differences between the chilling units required to start germination and to reach $100 \%$ germination and the differences between the chilling units required to achieve $50 \%$ and $100 \%$ germination show that the seeds of F1 cultivars (Campinas 1, Cristal, Real, Relíquia, Talismã, Marli, Premier, Biuti and Bolão) showed greater variability in both cases (660.11 CU and 393.78, CU respectively) when compared with seeds of F2 cultivars (Aurora-1, Alô Doçura, Josefina, Ouromel, Setembrino, Colibri and Convênio) (594.86 CU and 347.14, CU respectively) (Table 3).

Table 3. Correlations between accumulated chilling units required for 50\% and $100 \%$ germination with five phenological traits of 18 peach cultivars and one nectarine cultivar

\begin{tabular}{lccccc}
\hline $\begin{array}{l}\text { CU for } \\
\text { germination }\end{array}$ & $\begin{array}{c}\text { Early } \\
\text { bloom }\end{array}$ & $\begin{array}{c}\text { Full } \\
\text { bloom }\end{array}$ & $\begin{array}{c}\text { Early budding } \\
\text { (Date) }\end{array}$ & $\begin{array}{c}\text { Dormancy } \\
\text { break }^{\mathbf{1}}\end{array}$ & $\begin{array}{c}\text { Harvest } \\
\text { stage }\end{array}$ \\
\hline $50 \%$ & $0.70^{* *}$ & $0.72^{* *}$ & $0.42^{\text {ns }}$ & $0.40^{\text {ns }}$ & $0.04^{\text {ns }}$ \\
$100 \%$ & $0.55^{*}$ & $0.73^{* *}$ & $0.48^{*}$ & $0.50^{*}$ & $-0.12^{\text {ns }}$ \\
\hline
\end{tabular}

ns., **. *., non-significant, significant at 1 and $5 \%$ probability, respectively.

${ }^{1} 50 \%$ of vegetative buds at the green stage. 
Seeds from F1 plants are already F2 generation and therefore will show segregation in relation to the hybrid loci of the F1 cultivars. Seeds of F2 cultivars will have hybrid constitution in fewer loci than F1 plants and, therefore, their seeds, which are F3, will have less variability than the first seeds. Ramalho et al. (2001) discussed that the F1 progeny is heterozygous for all homozygous loci in which both parents differ and, in the F2 generation, 50\% of those loci will be heterozygous and $50 \%$ homozygous. This may explain the greater variability in the chilling requirements for germination of seeds from cultivars F1 and F2. Cultivar Topázio, although F2, showed the greatest difference between the chilling requirement to start germination and to achieve $100 \%$ germination. This may be due to its greater chilling requirement compared with the other cultivars, since it is more adapted to the climatic conditions of southern Brazil. Another possibility is that cv. Topázio has hybrid constitution in loci responsible for the chilling requirement.

\section{CONCLUSIONS}

Cultivar Campinas 1 was the first to bloom, to reach full bloom and dormancy break. Early fruit ripening was reached by cultivars Premier, Marli, Aurora-1, Setembrino, Josefina, Relíquia and Alô Doçura

Cultivars Campinas 1, Rei da Conserva, Alô Doçura, Josefina, Aurora-1, Ouromel, Talismã, Real, UFV 186, Colibri, Biuti, Reliquia, Setembrino, Premier and Cristal needed less accumulated chilling units for germination of all seeds.

Significant correlation was found between the chilling requirement for seed germination and phenological traits of blooming and between the chilling requirement for $100 \%$ germination and phenological data on budding.

There was no significant correlation between chilling requirements for germination and phenological data on peach harvest stage.

\section{REFERENCES}

Albuquerque AS (1997) Diversidade e parâmetros genéticos em pessegueiro (Prunus persica L. Batsch). Dissertação de Mestrado. Universidade Federal de Viçosa, Viçosa. 90p.

Albuquerque AS, Bruckner CH, Cruz CD \& Salomão LCC (2000) Avaliação de cultivares de pêssego e nectarina em Araponga, Minas Gerais. Revista Ceres, 47:401-410.

Antunes FZ (1985) Zoneamento agroclimático para fruteiras de clima temperado no Estado de Minas Gerais. Informe Agropecuário, 11:27-29.

Barbosa W, Bettiol Neto JE \& Dallorto FAC (2010) Pêssego e Nectarina. In: Donadio LC (Ed.) História da Fruticultura Paulista. $1^{\mathrm{a}}$ ed. Jaboticabal, SBF. p.285-302.

Barbosa W, Ojima M, Dall'Orto FAC \& Martins FP (1990a) Época e ciclo de maturação de pêssegos e nectarinas no Estado de São Paulo. Bragantia, 49:221-226.
Barbosa W, Ojima M, Dall'Orto FAC \& Martins FP (1990b) Pêssego: nova classificação dos cultivares do IAC para épocas de maturação dos frutos. O Agronômico, 42:103-105.

Cantillano RFF \& Sachs S (1984) Colheita, classificação, embalagem e armazenagem. In: Embrapa/Centro Nacional de Pesquisa em Fruteiras de Clima Temperado (Ed.) A cultura do pessegueiro. Pelotas, EMBRAPA/CNPFT. p.113-119.

Chang S \& Werner DJ (1984) Relationship of seed germination and respiration during stratification with cultivar chilling requirement in peach. Journal of the American Society for Horticultural Science, 109:42-45.

Citadin I (1999) Necessidade de calor para antese e brotação em pessegueiro [Prunus persica (L.) Batsch]. Dissertação de Mestrado. Universidade Federal de Pelotas, Pelotas. 74p.

Citadin I (2001) Necessidade de frio, herdabilidade da necessidade de calor e marcadores bioquímicos relacionados com o final de endodormênica em pessegueiro. Tese de Doutorado. Universidade Federal de Pelotas, Pelotas. 76p.

Citadin I, Raseira MCB, Quezada AC \& Silva JB (2003) Herdabilidade da necessidade de calor para a antese e brotação em pessegueiro. Revista Brasileira de Fruticultura, 25:119-123.

Cruz CD (2006) Programa Genes: Biometria. Viçosa, Editora UFV. $382 \mathrm{p}$.

Diaz DH \& Martin GC (1972) Peach seed dormancy in relation to endogenous inhibitors and applied growth substances. Journal of the American Society of Horticultural Science, 25:651-654.

García-Gusano M, Martínez-Gómez P \& Dicenta F (2004) Breaking seed dormancy in almond (Prunus dulcis (Mild.) D.A. Webb). Scientia Horticulturae, 99:363-370.

Guerriero R \& Scalabrelli G (1985) Effect of stratification duration on seed germination of several peach line rootstocks. Acta Horticulturae, 173:211-221.

Hauagge R (1988) Dormancy in Malus seeds and buds: phenotypic variations, characterization, correlations and inheritance. Doctoral Thesis. Cornell University, New York. 224p.

Hauagge R, Cummins JN \& Powell LE (1989) Relação entre a exigência em frio para quebra de dormência das sementes e das gemas das plantas resultantes em macieira (Malus spp.) In: Congresso Brasileiro de Fruticultura, Fortaleza. Anais, SBF. p. $270-284$.

Herter FG \& Feliciano AJ (1985) Exigência de calor para floração de pessegueiro, em Pelotas. Pelotas, EMBRAPA/CNPFT. 2p. (Pesquisa em Andamento, 26).

Kester DE (1969) Pollen effects on chilling requirements of almond and almond-peach hybrid seeds. Journal of the American Society for Horticultural Science, 94:318-321.

Kester DE, Raddi P \& Assay R (1977) Correlation of chilling requirements of germination, blooming and leafing within and among seedling populations of almond. Journal of the American Society for Horticultural Science, 102:145-148.

Mehanna HT, Martin GC \& Nishijuma C (1985) Effects of temperature, chemical treatments and endogenous hormone content on peach seed germination and subsequent seedling growth. Scientia Horticulturae, 27:63-73.

Moreno MAS (2005) Selección de patrones y variedades de melocotonero. Vida Rural, 206:28-32.

Pérez-Gonzalez S (1990) Relationship between parental blossom season and speed of seed germination in peach. HortScience, 25:958-960.

Pérez-Gonzalez S (1997) Genotypic differentiation in temperature requirements for stratification in peach. HortScience, 32:10641068 . 
Petri JL \& Herter FG (2004) Dormência e indução à brotação. In Monteiro LB, De Mio LL, Serrat BM, Motta ACV \& Cuquel FL (Eds.) Fruteiras de caroço: uma visão ecológica. Curitiba, Universidade Federal do Paraná. p.119-128.

Ramalho MAP, Abreu AFB \& Santos JB (2001) Melhoramento de espécies autógamas. In: Nass LL, Valois ACC, Melo IS \& Valadares-Inglis MC (Eds.) Recursos Genéticos e Melhoramento - Plantas. Rondonópolis, Fundação MT. p.201-230.

Raseira MCB, Herter FG \& Silva JB (1998) Correlação entre necessidades de frio da semente e da planta, como método de préseleção, em pessegueiro. Agropecuária de Clima Temperado, 1:177-182.

Raseira MCB \& Nakasu BH (1998) Cultivares: Descrição e Recomendação. In: Medeiros CAB \& Raseira MCB (Eds.) A cultura do pessegueiro. Brasília, Embrapa-SPI. p.29-99.

Richardson EA, Seeley SD \& Walker DR (1974) A model for estimating the completion of rest for 'Redhaven' and 'Elberta' peach trees. HortScience, 1:331-332.
Seeley SD \& Damavandy H (1985) Response of seed of seven deciduous fruits to stratification temperatures and implications for modeling. Journal of American Society for Horticultural Science, 110:726-729.

Selim HH, Omaima AK, Wafaa AE \& Tahany YH (1998) Physiological studies on propagation of Nemaguard peach seeds. Arab Universities Journal of Agricultural Sciences, 6:249-266.

Wagner Júnior A, Pimentel LD, Assis LMS, Alexandre RS \& Negreiros JRS (2006) Influence of fruit maturity stage in chilling requirement of peach seeds. Acta Horticulturae, 713:247-252.

Westwood MN \& Bjornstad HO (1968) Chilling requirement of dormant seed of 14 pear species as related to their climatic adaptation. Proceedings of the American Society for Horticultural Science, 92:141-149. 